\title{
The Motives for Inward FDI into Sub-Saharan African Countries
}

\begin{abstract}
This study contributes to the FDI literature by investigating the impact of all four locational motives of FDI in Sub-Saharan African (SSA) countries for the period 1996 - 2010. To achieve this aim, panel data techniques (pooled OLS, fixed effects and GMM) were employed on a sample of SSA countries. The empirical results showed that efficiency and strategic asset seeking factors influenced FDI activities in SSA for the period investigated. Market size also influenced FDI however this was less robust to specifications. Surprisingly, FDI in SSA was not resource seeking. Furthermore, a statistical test confirmed structural and behavioural differences in FDI determinants between SSA sub-regional groups and when analysed separately, FDI in West and Central SSA was market and efficiency seeking while FDI in South and East Africa was best explained by efficiency seeking factors. Based on the empirical findings, a number of policy implications were derived. These policy implications include further implementation of policies targeted at increasing and sustaining trade liberalisation and trade diversification, control of corruption, credible upgrades and productive investments in infrastructure, and support for human capital accumulation as FDI is increasingly directed towards R\&D, innovation and strategic asset activities.
\end{abstract}

Keywords - Foreign Direct Investment, Sub-Saharan Africa, Market Seeking, Resource Seeking, Efficiency Seeking, Strategic Asset Seeking

JEL Classification - F21; F68; H54; O55

\section{Introduction}

During the last three decades there has been a surge in foreign direct investment (FDI), although Sub-Saharan Africa still remains at the lower end of FDI recipient regions (Asiedu, 2002), accounting just 3\% of total global FDI (Darley, 2012). FDI in the region is also unevenly distributed with only a few SSA countries receiving a significant amount of the total FDI inflows. For instance, between 1987-1990 and 1995-1998, 33\% of the increase in FDI, and 41\% of average inflows of FDI went to four oil producing countries - Nigeria, Angola, Republic of the Congo and Equatorial Guinea (Ajayi, 2006). One thing that is clear is the benefits of FDI and the efforts of most developing countries to improve their business environments, liberalise policy regimes, and offer incentive packages to foreign investors in order to attract FDI (Waldkirch, 2011; Mottaleb and Kalirajan, 2010). Despite the poor past performance in attracting FDI inflow, there have been some slight increases in FDI over the last couple of decades which suggests that some factors have sufficiently improved. Therefore, one of the aims of this paper is to investigate how some of the determinants of FDI 
contribute to the slight increases seen in FDI in Sub-Saharan Africa and in particular how FDI activities in SSA are influenced by locational factors.

Theoretically, the determinants of FDI can be grouped into four main headings - theories assuming a perfect market, theories assuming imperfect markets, theories based on other factors, and other theories. These broad headings have been summarised into the Dunning's organisation, location and internalization (OLI) theory (Moosa, 2002). FDI studies based on country level data can only account for the locational aspect of the OLI paradigm. However, country level studies on FDI in developing countries and in particular Sub-Saharan Africa (SSA) have only focused on other locational factors that influence FDI activities such as those of resource, market and efficiency seeking. This means that the impact of the strategic asset on FDI activities in SSA has not been investigated. Thus, this study contributes to the FDI literature in SSA in the following ways. Firstly, all four locational motives of FDI were used to explain FDI activities into SSA. Secondly, SSA subregional groups were shown to have structural and behavioural differences in their FDI determinants. SSA Studies on FDI pool together all the countries in their sample without ascertaining if there are any structural and behavioural differences between groups. These contributions present an interesting and important addition to what is known about the motivation of firms to invest in SSA.

The study used panel data on a sample of countries for the period 1996-2010. Due to data limitations in collecting the strategic asset variable, the analysis on the impact of strategic asset variable on FDI in SSA used a sample of 13 countries while the rest of the analyses were based on a fuller sample of 36 SSA countries. Findings suggest that efficiency and strategic seeking factors influence FDI activities in SSA for the period investigated. Market size also influence FDI activities in SSA however, this was less robust to specifications. Conversely, natural resource endowment and investment in infrastructure which capture resource seeking motives are not positive and significantly related to FDI activities in SSA. Furthermore, a statistical test failed to accept the null hypothesis that the SSA sub-regional groupings are not different in their FDI determinants. When the sub-regional sample size was investigated individually, FDI in West and Central SSA can be said to be market and efficiency seeking while FDI in South and East Africa is best explained by efficiency seeking factors.

The remainder of this paper is structured as follows: section 2 is a brief literature review on FDI in SSA and section 3 discusses the determinants of FDI. Section 4 describes the data and sample. Section 5 specifies the model, presents the results and discusses the implications. Section 6 concludes.

\section{FDI in Sub-Saharan Africa}

Foreign direct investment is considered beneficial and vital (Alam and Shah, 2013) because of its package of tangible and intangible assets and the fact that firms who engage in these activities are important players in the global economy (Ajayi, 2006). In terms of the sources of capital flows, it 
is viewed as been more important than trade (Abbot and De Vita, 2011). The small share of FDI in the region can be attributed to a number of factors. Firstly, until very recently, countries in SSA regarded foreign capital with suspicion, often with good cause. Their fears were based largely on the likelihood of a loss of political sovereignty, an adverse impact on domestic firms due to increased competition and if foreign entrants mainly focus on natural resource sector, rapid economic degradation (Dupasquier and Osakwe, 2005). Therefore, many policies were introduced to deter foreign capital. The socialist development strategies adopted by many post-independence countries nationalised foreign companies and created state-owned industrial sectors. At the same time, SSA gained a reputation as an unattractive location for firms intending to compete in the marketplace due to political and economic risk, low quality of labour, the lack of infrastructures, highly inefficient and costly financial systems and the distance from export markets (Ezeoha and Cattaneo, 2011; Pigato, 2000).

Table 1 (panels A and B) reports the descriptive statistics of FDI inflows into SSA. Panel A shows that a few countries on average account for a significant proportion of the overall FDI inflows into the region. Likewise, the coefficient of variation in FDI inflows confirms the unequal distribution across countries. Panel B shows that when separated into sub-regional groups, West and Central SSA countries perform better compared to South and East SSA countries. However, the dispersion of FDI between the two groups is similar.

Table1: Country and Sub-regional Comparisons of FDI Inflows

\begin{tabular}{|c|c|c|c|c|c|}
\hline \multicolumn{6}{|c|}{ Panel A. FDI Inflows (1996-2010) } \\
\hline SSA Countries & Mean & Std. Dev. & Coef of Var. & Minimum & Maximum \\
\hline Angola & 0.817 & 1.705 & 2.088 & -3.227 & 3.505 \\
\hline Benin & 0.076 & 0.065 & 0.858 & 0.014 & 0.255 \\
\hline Botswana & 0.428 & 0.355 & 0.828 & -0.070 & 0.902 \\
\hline Burkina Faso & 0.060 & 0.096 & 1.609 & 0.004 & 0.370 \\
\hline Burundi & 0.001 & 0.003 & 2.276 & 0.000 & 0.012 \\
\hline Cameroun & 0.181 & 0.211 & 1.162 & -0.024 & 0.668 \\
\hline Cape Verde & 0.074 & 0.066 & 0.888 & 0.009 & 0.211 \\
\hline Central African Rep. & 0.029 & 0.032 & 1.102 & 0.001 & 0.117 \\
\hline Chad & 0.256 & 0.358 & 1.401 & -0.279 & 0.924 \\
\hline Cote d'Ivoire & 0.324 & 0.085 & 0.264 & 0.165 & 0.446 \\
\hline DRC Congo & 0.617 & 0.868 & 1.407 & -0.044 & 2.939 \\
\hline Equatorial Guinea & 0.488 & 0.562 & 1.150 & -0.794 & 1.636 \\
\hline Ethiopia & 0.269 & 0.158 & 0.585 & 0.022 & 0.545 \\
\hline Gabon & 0.051 & 0.233 & 4.556 & -0.489 & 0.320 \\
\hline Ghana & 0.551 & 0.732 & 1.327 & 0.059 & 2.527 \\
\hline Guinea & 0.099 & 0.122 & 1.228 & 0.002 & 0.386 \\
\hline Kenya & 0.115 & 0.176 & 1.539 & 0.005 & 0.729 \\
\hline Lesotho & 0.116 & 0.090 & 0.780 & 0.028 & 0.287 \\
\hline Madagascar & 0.307 & 0.426 & 1.389 & 0.010 & 1.169 \\
\hline Malawi & 0.063 & 0.053 & 0.841 & 0.006 & 0.176 \\
\hline Mali & 0.139 & 0.173 & 1.245 & 0.002 & 0.718 \\
\hline Mauritania & 0.137 & 0.224 & 1.630 & -0.038 & 0.814 \\
\hline Mauritius & 0.137 & 0.153 & 1.113 & -0.028 & 0.431 \\
\hline Mozambique & 0.334 & 0.252 & 0.753 & 0.064 & 0.893 \\
\hline Namibia & 0.176 & 0.222 & 1.261 & -0.031 & 0.796 \\
\hline
\end{tabular}




\begin{tabular}{cccccc} 
Niger & 0.162 & 0.306 & 1.887 & -0.001 & 0.947 \\
Nigeria & 3.463 & 2.708 & 0.782 & 1.005 & 8.555 \\
Rep. of the Congo & 0.909 & 1.070 & 1.177 & -0.009 & 2.816 \\
Rwanda & 0.026 & 0.039 & 1.489 & 0.002 & 0.119 \\
Senegal & 0.149 & 0.122 & 0.816 & 0.009 & 0.398 \\
South Africa & 3.079 & 3.063 & 0.995 & -0.184 & 9.645 \\
Sudan & 1.342 & 1.082 & 0.806 & 0.000 & 3.534 \\
Swaziland & 0.060 & 0.064 & 1.076 & -0.061 & 0.153 \\
Tanzania & 0.400 & 0.197 & 0.492 & 0.150 & 0.936 \\
The Gambia & 0.042 & 0.026 & 0.611 & 0.010 & 0.082 \\
Uganda & 0.386 & 0.279 & 0.723 & 0.121 & 0.817 \\
Zambia & 0.457 & 0.383 & 0.838 & 0.072 & 1.324 \\
\hline
\end{tabular}

(\$US billion, 1996 - 2010). Data Source: World Bank Development Indicators.

\begin{tabular}{lcrrrr}
\hline \multicolumn{5}{c}{ Panel B. sub-regional FDI inflows 1996-2010 } \\
\hline Sub-Regions & Mean & Std. Dev. & Coef of Var. & Minimum & Maximum \\
South and East Africa & 7.1442329 & 4.301538 & 0.602099344 & 2.159926 & 17.4371 \\
West and Central Africa & 9.1784885 & 7.058076 & 0.768980257 & 2.299092 & 20.4195 \\
\hline
\end{tabular}

(\$US billion, 1996 - 2010). Data Source: World Bank Development Indicators.

\section{Determinants of FDI}

\section{a. Theoretical Determinants of FDI}

Hymer and Kindleberger presented the first economic analysis of FDI and each independently refined the concepts and discussed the relationship between market structure in the home and host country. They also outlined the specific characteristics and advantages of investing firm, which could be used to explain the FDI decision (Hymer, 1976; Calvet, 1981). This was known as the industrial organisation theory which implies that due to the disadvantages foreign firms face when they compete in the host country, they must possess a set of countervailing advantages over local firms and that the market for such advantages must be imperfect (Kindleberger, 1969; Hymer, 1976). The internationalisation hypothesis is related to this and states that FDI arises when firms are able to replace market transactions with internal transactions (Buckley and Casson, 1976; Buckley and Casson, 2009). In so doing, the advantages enjoyed by the firms include lower transaction costs, the ability to minimise technology imitation and maintain reputation by effective management and quality control (De Beule and Bulcke, 2009). Although, before the industrial organisation and internationalisation hypotheses were developed to explain FDI activities, the differential rates of return hypothesis which stems from the trade theory was used to explain FDI. The differential rates of return hypothesis suggests that due to differences in relative factor intensities and factor endowments, capital will flow from capital abundant countries into capital scarce countries to exploit the higher rate of return where capital is less abundant (Calvet; 1981).

The location hypothesis assumes that FDI exists due to the international immobility of some factors, such as labour, knowledge, markets, and natural resources (Nagesh, 1994). Finally, the 
eclectic theory (OLI) which is a combination of the organisation, internalisation, and location hypotheses asserts that FDI takes place when firms possess ownership specific assets that can be internalised and exploited, which gives them an advantage in setting up production abroad (Dunning, 1980; Dunning, 1998). Without these conditions, foreign markets are best served exclusively through exports (Lim, 2001). However, due to data availability and the fact that most studies on FDI are based on country level analysis, the locational hypothesis of the OLI paradigm is the one most investigated in the FDI literature.

\section{b. Review of Some Empirical Studies on the Determinants of FDI}

There is a plethora of empirical studies on the determinants of FDI. For example, Mottaleb and Kalirajan (2010) ascribed the positive relationship between market size and FDI to the economic growth potential in the countries they investigated. Asiedu (2006) found that market size was positively related to FDI in a sample of small, low income countries and argued that one of the effects of regionalism which helps expand market size might have been a contributory factor.

Onyeiwu and Shresthe (2004) attributed the positive significance of natural resources to FDI to the fact that most of the countries in their sample are natural resource rich. Their sample focused on African countries and these countries, recorded unprecedented growth in natural resource endowments, accounting for about around 70\% of total FDI inflows into their region. Kolstad and Wiig (2012) also found a positive significant relationship between Chinese outward FDI and natural resources. Surprisingly, their study argued that the weak institutional environment in these host countries attracts Chinese firms due to the exploitative nature of Chinese firms. Bellak et al, (2008) used measures of information and communication infrastructure and found they had positive influences on FDI. Similarly, Fung and Siu (2005) used kilometres of paved road and concluded on the same positive impact. These findings were due to the fact that quality infrastructure increases productivity and thus attracts FDI. Kinda (2010) attributed the negative relationship between poor infrastructure and FDI to the increased transaction costs incurred as well as operational difficulties for foreign firms in the host country.

Ivohasina and Hamori (2005) found a positive relationship between return on capital and FDI because countries in their sample have scarce available finance and the lowest capital-labour ratio, and hence the highest return on capital. Majeed and Ahmad (2008) argued that the improved health conditions on workers through expenditures on health and the mass elementary education are possible factors responsible for the positive relationship of human capital to FDI. According to Tsen (2005), the positive relationship between human capital and FDI is due to the fact that foreign investment does not only seek to reduce costs but also acquire access to technology and innovative capacity. With respect to country risk, Egger and Winner (2005) claimed that corruption was beneficial in circumventing regulatory and administrative restrictions hence, the positive relationship with 
incumbent firms, although this is a barrier to the entry of new foreign investors. Conversely, Habib and Zurawicki (2002) argued that the operational inefficiencies that corruption generates in their sample account for the negative relationship between corruption and FDI. Anyanwu (2012) argued that the export oriented regimes pursued by the countries in their study have contributed to the positive relationship between trade openness and FDI. Masuku and Dlamini (2009) and Asiedu (2002) all showed positive relationships between trade openness and FDI due to lower transaction costs associated with liberalised trade regimes. Studies by Wadhwa and Reddy (2011), Udoh and Egwaikhide (2008), and Ahn (1998) all showed that inflation was negatively related with FDI. The reasons for this negative relationship are that inflation leads to macroeconomic instability and is a potential risk for foreign investors. Pradhan (2010) showed that the desire to acquire strategic assets through the accumulation of new technology, marketing skills and operational capabilities has led Indian MNEs to move some of their activities across borders.

\section{Sample and Data}

\section{a. Sample Countries}

Table 2 shows the sample of countries used in this study. Due to gaps in the data, not all SSA countries are included. Furthermore, Equatorial Guinea was removed as it was found to be an outlier relative to the rest of the sample.

Table 2 Sample Countries

\begin{tabular}{|c|c|c|c|c|c|c|c|}
\hline $\begin{array}{l}\text { Angola } \\
\text { Central African }\end{array}$ & Benin & Botswana** & Burkina Faso & Burundi & Cameroun** & Cape Verde & \\
\hline Rep. & Chad & Cote d'Ivoire & DRC Congo & Equatorial Guinea* & Ethiopia & Gabon** & \\
\hline Ghana** & Guinea & Kenya** & Lesotho & Madagascar & Malawi & $\begin{array}{l}\text { Mali } \\
\text { Rep. of }\end{array}$ & \\
\hline Mauritania & $\begin{array}{l}\text { Mauritius } \\
\text { South }\end{array}$ & Mozambique** & Namibia** & Niger & Nigeria** & Congo & Rwanda \\
\hline Senegal** & Africa** & Sudan** & Swaziland & Tanzania** & The Gambia & Uganda & Zambia** \\
\hline \multicolumn{8}{|c|}{ Panel A. Note: * Removed on account of been an outlier; ** Indicate the 13 countries used to investigate strategic asset motives } \\
\hline Angola & Botswana & Ethiopia & Kenya & Lesotho & Madagascar & Malawi & Mauritius \\
\hline Mozambique & Namibia & South Africa & Swaziland & Tanzania & Uganda & Zambia & \\
\hline \multicolumn{8}{|c|}{ Panel B. South \& East SSA Countries } \\
\hline Benin & Burkina Faso & Burundi & Cameroun & Cape Verde & $\begin{array}{l}\text { Central African } \\
\text { Rep. }\end{array}$ & Chad & \\
\hline Cote d'Ivoire & DRC Congo & Gabon & Ghana & Guinea & Mali & Mauritania & \\
\hline Niger & Nigeria & Rep. of Congo & Rwanda & Senegal & Sudan & The Gambia & \\
\hline
\end{tabular}

Panel C. West and Central SSA Countries. Note: Sudan was included in this sub-region

\section{b. Variable Description}

All the data used for this study were obtained from secondary sources. These sources include the World Bank Development Indicators, UNCTAD, World Bank Governance Indicators, and the 
United States Energy Statistics Database. The variables employed to capture the four FDI locational motives were hugely dependent on data availability.

\section{(i) Dependent Variable}

FDI as a percentage of GDP was used as the dependent variable. For most FDI studies, this is a standard measure. It captures the net flows of investment as a percentage of GDP made by foreign investors in a host country for the purposes of acquiring lasting management interests.

\section{(ii) Market Seeking Variable}

The study used growth rate of per GDP to measure the size of the host country's domestic market. Some of the objectives of FDI often include producing in the host country and serving the local market. Hence, any increase in the size of the local market is viewed by market seeking FDIs as an opportunity to enter host market (Asiedu, 2002). GDP per capita is the gross domestic product divided by midyear population. The hypothesis is that FDI will be attracted to countries with higher GDP per capita growth as it demonstrates large market size.

\section{(iii) Resource Seeking Variables}

This study used three measures to capture the availability of resources. These are natural resource rent, investment in infrastructure, and cost of fuel. Huge rents from natural resources signal the abundance and low cost of natural resources in the host country. The availability of natural resources is an incentive for FDI especially in the case of developing countries. One argument is that, unlike measures of market size, natural resources in particular serve both home and international markets (Kinoshita and Campos, 2002). Similarly, credible investments in infrastructure can stimulate FDI through its positive impact on the productivity of investments. However, any increases in the cost of fuel in the host country would most likely deter FDI as it adds to the associated costs on investment. The hypothesis is that both natural resource rent and investment in infrastructure would positively influence FDI while cost of fuel will exert a negative relationship on FDI.

(iv) Efficiency Seeking Variables

Macroeconomic factors, human resources, and quality of institutions are locational factors that equally determine FDI. The return on capital, trade openness and inflation were used to capture macroeconomic factors while corruption and enrolment rate in education were used to capture quality of institutions and the availability of human resources respectively. In theory, FDI will go to countries that offer a higher return on capital. It is particularly the case in capital scarce developing countries because investments yield a higher rate of return. However, the inefficient capital markets in the region presents a difficulty in measuring the return on capital hence, the use of the inverse of real 
GDP per capita as a proxy. This proxy follows in line to those of Edwards (1990) and Asiedu (2002) who assume that the marginal product of capital is equal to the rate of return and used this proxy in their models. Therefore, investments in countries with a higher per capita income should yield a lower return which means that the logarithm of real GDP per capita should be inversely related to FDI. Inflation measured the annual percentage change in the cost of acquiring goods and services in the host country. As in the standard literature, trade openness was measured as the share of trade (imports and exports) in GDP. Host countries with open economies will be attractive especially to export oriented FDIs as transaction costs that result from market imperfections will be reduced.

Host countries characterised by corruption as a result of weak institutions are most likely to deter FDI (Asiedu, 2006). To capture this variable, the degree to which the abuse of power for private gain is perceived was used. Quality of human capital and the raising of human capital through education and skill acquisition positively influence FDI. This study employed the secondary school enrolment rates to capture the availability and quality of human capital. The hypothesis is that return on capital, trade openness, enrolment rate in education will have a positive impact on FDI while corruption and inflation will negatively impact on FDI.

\section{(v) Strategic Asset Seeking Variable}

Opportunities offered for the exchange of localised tacit knowledge, ideas, interactive learning, and the need to harness such assets have become very important strategic motives for FDI (Dunning, 1998). To capture the strategic asset seeking variable, the study used the number of mergers and acquisition (M\&A). It is often argued that the desire to lend further support to the strategic asset seeking motivation of firms is reflected in the current wave of merger and acquisition (M\&A) activity. This enables firms to accumulate new technology, marketing skills and operational capabilities (Pradhan, 2010). Bertrand et al, (2007) showed that M\&A is to a larger extent motivated by asset seeking motives. The hypothesis is that the strategic asset seeking variable will have a positive relationship with FDI.

\section{c. Preliminary Data Analysis}

Tables 3 and 4, report the correlation matrix and summary statistics respectively. The correlation coefficients indicate no high multicollinearity between the variables. The descriptive statistics show that there are some differences in the full sample means and sub-regional means. For example, value of GDP per capita growth, human capital, and investment in infrastructure are greater in the South and East SSA countries. On the other hand, West and Central SSA countries have greater natural resources endowments, attract more FDI as a share of GDP and better macroeconomic stability but have a higher level of corruption. 
Table 3 Correlation Matrix

\begin{tabular}{|c|c|c|c|c|c|c|c|c|c|c|c|}
\hline & & 1 & 2 & 3 & 4 & 5 & 6 & 7 & 8 & 9 & 10 \\
\hline 1 & FDI of GDP & 1 & & & & & & & & & \\
\hline 2 & GDP per Capita (Growth) & 0.107 & 1.000 & & & & & & & & \\
\hline 3 & Natural Resource Rent & 0.280 & 0.061 & 1.000 & & & & & & & \\
\hline 4 & Infrastructure Investment, US \$ (Log) & 0.027 & -0.037 & 0.076 & 1.000 & & & & & & \\
\hline 5 & Cost of Fuel & 0.026 & -0.013 & -0.109 & 0.087 & 1.000 & & & & & \\
\hline 6 & Rate of Return, Log & -0.044 & -0.099 & -0.215 & -0.183 & 0.100 & 1.000 & & & & \\
\hline 7 & Enrolment Rate in Education & -0.006 & 0.073 & -0.150 & 0.144 & -0.062 & -0.744 & 1.000 & & & \\
\hline 8 & Corruption & 0.078 & -0.108 & 0.485 & -0.027 & 0.015 & 0.447 & -0.600 & 1.000 & & \\
\hline 9 & Trade Openness & 0.309 & 0.092 & 0.318 & 0.019 & -0.123 & -0.506 & 0.351 & -0.248 & 1.000 & \\
\hline 10 & Inflation & 0.014 & 0.026 & 0.139 & -0.075 & -0.096 & 0.024 & -0.059 & 0.101 & 0.097 & 1.000 \\
\hline
\end{tabular}

anel B. 13 SSA Countries

\begin{tabular}{|c|c|c|c|c|c|c|c|c|c|c|c|c|}
\hline & & 1 & 2 & 3 & 4 & 5 & 6 & 7 & 8 & 9 & 10 & 11 \\
\hline 1 & FDI of GDP & 1.000 & & & & & & & & & & \\
\hline 2 & GDP per Capita (Growth) & 0.278 & 1.000 & & & & & & & & & \\
\hline 3 & Natural Resource Rent & -0.058 & -0.107 & 1.000 & & & & & & & & \\
\hline 4 & Infrastructure Investment, US \$ (Log) & -0.003 & -0.044 & -0.006 & 1.000 & & & & & & & \\
\hline 5 & Cost of Fuel & 0.116 & 0.076 & -0.148 & 0.282 & 1.000 & & & & & & \\
\hline 6 & Rate of Return, Log & 0.205 & 0.207 & -0.277 & 0.038 & -0.103 & 1.000 & & & & & \\
\hline 7 & Enrolment Rate in Education & -0.039 & -0.153 & -0.004 & 0.199 & 0.173 & -0.549 & 1.000 & & & & \\
\hline 8 & Corruption & -0.073 & -0.061 & 0.440 & -0.016 & -0.108 & 0.468 & -0.379 & 1.000 & & & \\
\hline 9 & Trade Openness & 0.007 & -0.120 & 0.267 & -0.070 & 0.000 & -0.439 & 0.421 & -0.428 & 1.000 & & \\
\hline 10 & Inflation & 0.045 & 0.101 & -0.105 & -0.097 & -0.257 & 0.316 & -0.117 & 0.146 & -0.105 & 1.000 & \\
\hline 11 & M\&A & -0.106 & -0.064 & -0.150 & 0.205 & 0.028 & -0.323 & 0.297 & -0.370 & -0.137 & -0.050 & 1.000 \\
\hline
\end{tabular}

Note that the negative and positive correlation coefficients the between return on capital and FDI as a percentage of GDP can be explained by the fact that the variable is already in logarithm term and considering it has been proxied using the inverse of real GDP per capita.

Table 4 Summary Statistics

\begin{tabular}{|c|c|c|c|c|c|c|c|c|}
\hline \multirow{2}{*}{$\begin{array}{l}\text { Sample Countries } \\
\text { Variables } \\
\end{array}$} & \multicolumn{4}{|c|}{ Total Sample } & \multicolumn{2}{|c|}{$\begin{array}{l}\text { West \& Central } \\
\text { Africa }\end{array}$} & \multicolumn{2}{|c|}{ South \& East Africa } \\
\hline & Mean & Std. Dev. & Min & Max & Mean & Std. Dev. & Mean & Std. Dev. \\
\hline FDI of GDP & 3.793 & 5.445 & -8.139 & 46.501 & 3.843 & 6.094 & 3.724 & 4.389 \\
\hline GDP per Capita (Growth) & 2.162 & 3.773 & -15.306 & 29.104 & 1.669 & 3.802 & 2.852 & 3.629 \\
\hline Natural Resource Rent & 11.520 & 16.263 & 0.006 & 78.552 & 14.568 & 17.618 & 7.254 & 13.039 \\
\hline Infrastructure Investment, US \$ (Log) & 5.428 & 3.648 & 0.000 & 9.763 & 5.041 & 3.799 & 5.969 & 3.359 \\
\hline Cost of Fuel & 1.808 & 0.228 & 0.477 & 2.228 & 1.818 & 0.231 & 1.794 & 0.224 \\
\hline Rate of Return, Log & -3.161 & 0.409 & -4.178 & -2.352 & -3.082 & 0.351 & -3.272 & 0.457 \\
\hline Enrolment Rate in Education & 32.239 & 21.620 & 5.169 & 95.700 & 26.924 & 16.026 & 39.680 & 25.872 \\
\hline Corruption & 65.970 & 22.050 & 14.146 & 99.998 & 72.382 & 19.221 & 56.994 & 22.656 \\
\hline Trade Openness & 74.060 & 36.209 & 17.859 & 202.850 & 66.670 & 29.930 & 84.405 & 41.410 \\
\hline Inflation & 21.975 & 182.991 & -9.616 & 4145.107 & 13.662 & 49.224 & 33.613 & 277.390 \\
\hline
\end{tabular}




\section{Models, Estimations and Results}

\section{a. Model specification}

The paper uses panel data techniques (pooled OLS, fixed effects and GMM) on 36 SSA countries for the period 1996-2010. These countries were further divided into sub-regional groups within SSA. Then a subset of 13 countries was used to investigate the influence of the strategic asset variable on FDI, given these were the only countries for which this data was available. The 1996 was chosen as the starting point as this period following reflects a time of overall recovery for the region after decades of little or no investment and economic decline. Periods after 2010 present no comprehensive data for most of the countries in the sample.

To model the determinants of foreign investment the estimating equation can be stated as follows:

$$
\mathrm{y}_{\mathrm{it}}=\alpha_{\mathrm{i}}+\beta_{1} \mathrm{X}_{1 \mathrm{it}}+\beta_{2} \mathrm{X}_{2 \mathrm{it}}+\ldots \ldots+\mu_{\mathrm{i}}+\mathrm{v}_{\mathrm{it}}
$$

where:

$\mathrm{y}=$ FDI inflows as percentage of GDP in country $i$ and at time $t, X_{i t}$ is a matrix of independent variables, $\beta=$ is a vector of coefficients to be estimated and $\mathrm{u}_{\mathrm{it}}$ are the error terms.

$$
\text { Iit }=\beta 11 i, t-1+\beta 1 I i, t-2+\beta 2 K i t+\beta 3 X i t+\mu_{i t}
$$

$I$ is FDI inflows as a percentage of GDP in country $i$ and Ii,t-1 and Ii,t-2 are the lagged values of FDI as a percentage of GDP in country $i$ at time $t, \mathrm{X}_{i t}$ is a matrix of independent variables, Kit is a matrix of the components of the dependent variables

The model was initially estimated using pooled OLS for the full sample only (model 1) and then subsequently using fixed effects and GMM. The Hausman test favoured the fixed effects over the random effects estimations. To test whether the regional sub-groups were behaviourally and structurally different a Chow Test was conducted. The value of the F test was 4.015 and since it is greater that the $\mathrm{F}$ distribution at 10\% (1.42), 5\% (1.57) and 1\% (1.88) the null hypothesis was not accepted. Thus, the regional sub-groups were separated and investigated in models 4 and 5 . Results for all the models report robust standard errors. This was because a Breusch-Pagan/Cook-Weisberg Test for heteroskedasticity suggested the presence of heteroskedasticity and to relax the assumption that the errors were both independent and identically distributed, robust standard errors are reported.

The fixed effects model was favoured over the random effects model by the Hausman test. Further tests such as unit root test and co-integration tests are not feasible for this study considering the rather small time period this study employed. Such tests are better fitted for panels with very long time periods. Hence, the absence of these tests would not bias any results obtained. Also, the modelling techniques especially fixed effects and GMM would allow for variation in the 
characteristics of the countries in the sample as well control for unobserved effects, possible endogeneity, unobserved heterogeneity, and when the explanatory variables employed are not strictly exogenous. Using GMM in models 4, 5 and 6 would not be feasible as the number of samples in these models is small relative to the time period.

\section{b. Results and Discussions}

The regression results are in table 9. The least favoured estimation is the pooled OLS (model 1). This is due to the advantages fixed effects and GMM have over pooled OLS. Therefore, the discussion will be largely restricted to models 2 to 6 . The market seeking motives of FDI were tested using GDP per Capita and the finding produced mixed results. While it was positively significant in the full sample (model 2) and the West and Central SSA sub-sample, it was positive and insignificant in the South and East SSA sub-sample. These findings suggest that FDI in West and Central SSA is more market seeking compared to South and Eastern SSA, which might be more export oriented.

Natural resource rent, investment in infrastructure, and cost of fuel were used to test the resource seeking motives. Surprisingly, natural resource rent was negatively significant in both the full and sub-regional sample. This is in contrast to what is expected as the decision to undertake FDI in developing countries is frequently influenced by the presence of natural resources. This relationship between natural resource rent and FDI should not be taken literally to mean that the abundance of natural resources is a disincentive for FDI in SSA. The following plausible explanations are provided to justify this negative relationship. First, local currency can appreciate as a result of huge rent generated from natural resources. This appreciation of local currency can crowd out investment in non-natural resource tradable sectors as a country's exports have already become less competitive (Corden and Neary, 1982). Second, countries with higher percentage of minerals and fuels in total merchandise exports are more prone to external shocks since they are not good in trade diversification. This can result in a decline in FDI as these shocks create macroeconomic instability. Most countries in SSA have experienced appreciated local currency as a result of natural resources, have a higher percentage of minerals and fuels in total exports and are very poor in trade diversification. Third, in SSA countries, huge amounts of natural resources remain unused due misplaced priorities and ongoing conflicts between interest groups. Well known cases of militancy and conflicts in Nigeria, Liberia, Sierra Leone, Angola, DRC and the Republic of Congo have halted the exploration and production of natural resources thereby impacting negatively on investments. Asiedu and Lien (2011) had similar findings. 
Table 5 Regression Results (in parentheses are robust standard errors)

\begin{tabular}{|c|c|c|c|c|c|c|}
\hline FDI of GDP (Dependent Variable & $\begin{array}{c}\text { Panel OLS } \\
\text { Model 1 } \\
\text { All Sample SSA } \\
\text { Countries }\end{array}$ & $\begin{array}{c}\text { Fixed Effects } \\
\text { Model } 2 \\
\text { All Sample SSA } \\
\text { Countries }\end{array}$ & $\begin{array}{c}\text { GMM } \\
\text { Arellano Bond } \\
\text { Model } 3 \\
\text { All Sample SSA } \\
\text { Countries }\end{array}$ & $\begin{array}{c}\text { Fixed Effects } \\
\text { Model } 4 \\
\text { West \& Central } \\
\text { African SSA }\end{array}$ & $\begin{array}{c}\text { Fixed Effects } \\
\text { Model } 5 \\
\text { South \& East } \\
\text { SSA Countries }\end{array}$ & $\begin{array}{c}\text { Fixed Effects } \\
\text { Model } 5 \\
\text { Model } 6 \\
\text { 13 SSA } \\
\text { Countries }\end{array}$ \\
\hline \multicolumn{7}{|l|}{ Independent Variables } \\
\hline FDI of GDP, Lagged One Year & & & $\begin{array}{l}0.228^{*} \\
(0.126)\end{array}$ & & & \\
\hline FDI of GDP, Lagged Two Year & & & $\begin{array}{l}-0.036 \\
(0.077)\end{array}$ & & & \\
\hline GDP per Capita (Growth) & $\begin{array}{c}4.607 \\
(3.807)\end{array}$ & $\begin{array}{l}8.545^{*} \\
(5.002)\end{array}$ & $\begin{array}{c}0.018 \\
(0.099)\end{array}$ & $\begin{array}{c}0.313^{* * * *} \\
(0.101)\end{array}$ & $\begin{array}{c}0.001 \\
(0.001)\end{array}$ & $\begin{array}{l}2.440 \\
(2.757)\end{array}$ \\
\hline Natural Resource Rent & $\begin{array}{l}-0.134 \\
(0.087)\end{array}$ & $\begin{array}{l}-0.147^{*} \\
(0.082)\end{array}$ & $\begin{array}{c}-0.339 * * * \\
(0.095)\end{array}$ & $\begin{array}{l}-0.169 * \\
(0.102)\end{array}$ & $\begin{array}{c}-0.178^{* *} \\
(0.089)\end{array}$ & $\begin{array}{c}0.045 \\
(0.047)\end{array}$ \\
\hline Infrastructure Investment, US \$ (Log) & $\begin{array}{c}0.121 \\
(0.082)\end{array}$ & $\begin{array}{l}-0.007 \\
(0.074)\end{array}$ & $\begin{array}{c}0.041 \\
(0.139)\end{array}$ & $\begin{array}{c}0.086 \\
(0.098)\end{array}$ & $\begin{array}{l}-0.079 \\
(0.117)\end{array}$ & $\begin{array}{c}0.003 \\
(0.067)\end{array}$ \\
\hline Cost of Fuel & $\begin{array}{l}-0.420 \\
(4.255)\end{array}$ & $\begin{array}{c}-11.926 * * \\
(5.249)\end{array}$ & $\begin{array}{l}-1.159 \\
(7.466)\end{array}$ & $\begin{array}{c}-5.957 * * * \\
(2.137)\end{array}$ & $\begin{array}{c}-9.362 * * \\
(4.497)\end{array}$ & $\begin{array}{c}-4.429 * * * \\
(1.204)\end{array}$ \\
\hline Rate of Return & $\begin{array}{c}17.472^{* * *} \\
(6.163)\end{array}$ & $\begin{array}{c}42.807 * * * \\
(8.237)\end{array}$ & $\begin{array}{c}44.974 * * * \\
(11.369)\end{array}$ & $\begin{array}{c}27.183^{* * *} \\
(9.357)\end{array}$ & $\begin{array}{c}44.869 * * * \\
(8.876)\end{array}$ & $\begin{array}{c}2.011 \\
(6.503)\end{array}$ \\
\hline Enrolment Rate in Education & $\begin{array}{c}0.242 * * * \\
(0.046)\end{array}$ & $\begin{array}{c}0.132 * * * \\
(0.045)\end{array}$ & $\begin{array}{l}0.175^{*} \\
(0.105)\end{array}$ & $\begin{array}{l}0.164^{* *} \\
(0.068)\end{array}$ & $\begin{array}{c}0.087 * * * \\
(0.033)\end{array}$ & $\begin{array}{c}0.047^{* *} \\
(0.019)\end{array}$ \\
\hline Corruption & $\begin{array}{c}-0.049 * * \\
(0.021)\end{array}$ & $\begin{array}{c}-0.065^{* * *} \\
(0.021)\end{array}$ & $\begin{array}{c}-0.108 * * \\
(0.048)\end{array}$ & $\begin{array}{l}-0.053^{*} \\
(0.029)\end{array}$ & $\begin{array}{l}-0.045^{*} \\
(0.025)\end{array}$ & $\begin{array}{l}-0.039 * \\
(0.020)\end{array}$ \\
\hline Trade Openness & $\begin{array}{c}0.126 * * * \\
(0.041)\end{array}$ & $\begin{array}{c}0.122^{* * *} \\
(0.041)\end{array}$ & $\begin{array}{c}0.132 * * \\
(0.058)\end{array}$ & $\begin{array}{l}0.107^{*} \\
(0.063)\end{array}$ & $\begin{array}{l}0.088^{*} \\
(0.047)\end{array}$ & $\begin{array}{c}0.022 \\
(0.016)\end{array}$ \\
\hline Inflation & $\begin{array}{c}-0.002^{* *} \\
(0.001)\end{array}$ & $\begin{array}{c}-0.002 * * \\
(0.001)\end{array}$ & $\begin{array}{c}0.003 \\
(0.009)\end{array}$ & $\begin{array}{c}0.005 \\
(0.007)\end{array}$ & $\begin{array}{c}-0.002^{* * *} \\
(0.001)\end{array}$ & $\begin{array}{l}-0.015 \\
(0.013)\end{array}$ \\
\hline Mergers \& Acquisition & & & & & & $\begin{array}{l}0.081^{* *} \\
(0.032)\end{array}$ \\
\hline Cons. & $\begin{array}{c}47.628 * * * \\
(16.954)\end{array}$ & $\begin{array}{c}128.604^{* * *} \\
(22.202)\end{array}$ & & $\begin{array}{c}85.033^{* * * *} \\
(25.532)\end{array}$ & $\begin{array}{c}170.391^{* * *} \\
(33.000)\end{array}$ & $\begin{array}{c}1.326 \\
(23.601)\end{array}$ \\
\hline Arellano Bond AR1(1) & & & -2.86 & & & \\
\hline Arellano Bond AR(2) & & & 0.70 & & & \\
\hline Wald Chi2 & & & 390.76 & & & \\
\hline Sargan (88) & & & 219.74 & & & \\
\hline Hansen (88) & & & 16.85 & & & \\
\hline No. of Obs. & 540 & 540 & & 315 & 225 & 195 \\
\hline F Stat & 9.01 & 7.25 & & 6.92 & 4.32 & 10.08 \\
\hline Prob. $>$ F & 0.0000 & 0.0000 & & 0.0000 & 0.0000 & 0.0000 \\
\hline R Squared & 0.4003 & 0.4709 & & 0.5006 & 0.5091 & 0.6338 \\
\hline
\end{tabular}


Investment in infrastructure was insignificantly related to FDI in all of the models. Though, a positive and significant relationship was expected, the insignificant relationship was nevertheless not surprising. SSA countries spend less in improving and upgrading available infrastructure which can productivity to investments. Poor road networks, electricity generation, weak communication systems are some of the obstacles of doing business in SSA countries. For instance, most firms operating in SSA use private generators as electricity supply is very unreliable. This insignificant relationship is further supported by the negative and insignificant relationship between cost of fuel and FDI. As most firms are affected by electricity supply, poor communication systems, and poor transportation networks, any alternatives to circumvent these problems with alternative means which might require the extensive use of fuel would mostly likely increase the costs of investment.

The efficiency seeking motives were tested using rate of return, enrolment rate in education, corruption, trade openness, and inflation. The findings were all as expected. The return on capital was positive and significant both for the full SSA sample and sub-regional groups. SSA countries are regarded as being too risky for investment and thus, high return well enough to compensate for any possible risk can still spur on investment. These results also confirm the hypothesis that all things being equal, capital will flow from capital abundant countries into capital scarce countries such as SSA in order to exploit the higher return on capital. Enrolment rate in education was positive and significant in all the models. These results demonstrate the importance of human capital accumulation in attracting FDI. In recent years, SSA countries with the assistance of the international communities have pursued programmes targeted at improving education and the quality of human capital available in the region.

Corruption as expected was negatively significant in all the models. Potential investors are easily deterred by the presence of corruption and with SSA countries still to win and sustain the fight against corruption, it very evident this is impacting negatively on investment. Trade openness is found to have a positive and significant impact both in the full sample and in the sub-regional groups. These results suggest that trade liberalisation is a determining factor for FDI and improvements in policies that liberalise trade regimes which SSA countries have pursued in the last couple of decades do have an impact on investment. Inflation was negative and significant in the full sample and the South and East SSA sub-sample however, it was insignificant in the West and Central SSA countries. Very high level inflation is known to erode the value of investment and assets. The negative and insignificant relationship between inflation and FDI in the South and East SSA sub-sample was not so surprising considering that inflation around the mean in South and East SSA countries is more than double that of the West and Central SSA countries. 
The results in model 6 relate to the strategic asset variable, proxied by the number of mergers and acquisitions. This is found to have a positive and significant influence on FDI inflows. These results suggest that FDI in the region are strategic and asset seeking. Some SSA countries in recent years have pursued and developed capabilities in the areas of technology and innovation which are some of the main motives of strategic asset seeking FDIs.

\section{Conclusion}

This paper contributes to the FDI literature by investigating the locational motives of inward FDI in SSA countries. This includes whether recent FDI activities in SSA are strategically asset motivated. Furthermore, the study examines whether there are structural and behavioural differences relating to FDI between sub-regions in SSA. Thus, the paper is a departure from the approach taken by the majority of FDI studies which focus on other location influencing factors such as resource, market and efficiency criteria as well as pooling all different countries in one sample regardless of any structural or behavioural differences. Panel data was used on samples of SSA countries for the period 1996-2010. The methods include pooled OLS regression, fixed effects and GMM estimations.

The findings confirm that market size, return on capital, human capital and trade openness have positive and significant relationships with FDI. On the other hand, rent from natural resources, corruption, inflation and cost of fuel have negative and significant relationships with FDI. Findings also show that recent FDI inflows in SSA have been motivated by strategic assets and that subregional groups in SSA are structurally and behaviourally different in their FDI determinants. In summary, recent FDI activities in SSA are motivated by market, efficiency and strategic asset seeking variables but are not by resource seeking. However, when investigated separately, FDI in West and Central SSA countries is most likely to be motivated by market and efficiency seeking variables while FDI in South and East Africa is most likely to be influenced by efficiency seeking variables.

Based on these findings, a number of policy implications can be derived. First, trade liberalisation has improved the business environment in SSA and it is important that this is continually maintained. Second, high levels of corruption are disincentives for foreign investment and hence should be curtailed through quality institutions. International organisations and partners can support these efforts at improving and stabilising democratic institutions in SSA. While some SSA countries have only recently tried to address the issues of corruption many are yet to. Third, SSA countries endowed with natural resources should pursue policies targeted at trade diversification and the implementation of sound policies that can help tackle the over appreciation of local currency. Also, the conflict and instability often generated as a result of natural resources must be addressed in order to maximise the exploration and production of natural resources and encourage a fair 
distribution of the wealth that results. Fourth, investment in the development of basic and productive infrastructures should be encouraged. It is very common for developing countries to spend on projects which are hard to monitor thereby neglecting the needed projects which would boost investment. Fifth, with asset seeking motives strongly related to FDI, state support for human capital accumulation is important as FDI is increasingly directed towards R\&D and innovation activity. Thus, asset-seeking FDIs will widen the region's access to new markets, new technologies and product development competencies that result in spillovers from foreign firms to the domestic economy.

\section{References}

Abbot, A. J., and De Vita, G., (2011). Evidence on the Impact of Exchange Rate Regimes on Bilateral FDI Flows, Journal of Economic Studies, 38(3), 253-274

Ahn, Y. S., Adji, S. S. and Willet, T. D., (1998). The Effects of Inflation and Exchange rate Policies on Direct Investment to Developing Countries, International Economic Journal, 12(1), 95104

Ajayi, S. I., (2006). Foreign Direct Investment in Sub Saharan Africa: Origins, Targets, Impact and Potential, African Economic Research Consortium

Alam, A., and Shah, S. Z. A., (2013). Determinants of Foreign Direct Investment in OECD Member Countries, Journal of Economic Studies, 40(4), 515-527

Anyanwu, J. C., (2012). Why Does Foreign Direct Investment Go Where it Goes? New Evidence From African Countries, Annals of Economics and Finance, 13(2), 433-470

Asiedu, E., (2002). On the Determinants of Foreign Direct Investment to Developing Countries: Is Africa Different?, World Development, 30(1), 107-119

Asiedu, E., (2006). Foreign Direct Investment in Africa: The Role of Natural Resources, Market Size, Government Policy, Institutions and Political Instability, The World Economy, 29(1), 6377

Asiedu, E., and Lien, D., (2011). Democracy, Foreign Direct Investment and Natural Resources, Journal of International Economics, 84(1), 99-111

Bellak, C., Leibrecht M. and Riedl, A., (2008). Labour Costs and FDI Flows into Central and Eastern European Countries: A Survey of the Literature and Empirical Evidence, Structural Change and Economic Dynamics, 19(1), 17-37

Bertrand, O., Hakkala, K., and Norback, P., (2007). Cross-Border Acquisition or Greenfield Entry: Does it Matter for Affiliate R\&D? Research Institute of Industrial Economics Working Paper No. 693

Buckley, P. J., and Casson, M. C., (2009). The Internalisation Theory of the Multinational Enterprise: A Review of the Progress of a Research Agenda After 30 Years, Journal of International Business Studies, 40, 1563-1580

Buckley, P. J., and Casson, M., (1976). The Future of the Multinational Enterprise, London: The Macmillan Press.

Calvet, A. L., (1981). A Synthesis of Foreign Direct Investment Theories and Theories of Multinational Firm, Journal of International Business Studies, 12, 43-59

Corden, Max W., and Neary, J. Peter, (1982). Booming Sector and De-Industrialization in Small Open Economy, The Economic Journal, 92 (368), 825-848

Darley, W. K., (2012). Increasing Sub-Saharan Africa's Share of Foreign Direct Investment: Public Policy Challenges, Strategies, and Implications, Journal of African Business, 13(1), 62-69

De Beule, F., and Bulcke, D. V., (2009). Retrospective and Prospective Views About the Future of the Multinational Enterprise, International Business Review, 18(3), 215-223 
Dunning, J. H., (1980). Toward an Eclectic Theory of International Production: Some Empirical Tests, Journal of International Business Studies, 11, 9-31

Dunning, J. H., (1998). Location and the Multinational Enterprise: A Neglected Factor, Journal of International Business Studies, 29(1), 45-66

Dupasquier, C., and Osakwe, P., (2005), Foreign Direct Investment in Africa: Performance, Challenges and Responsibilities, African Trade Policy Centre Working Paper, No. 25

Edwards, S., (1990). Capital Flows, Foreign Direct Investment and Debt-Equity Swaps in developing Countries, NBER Working paper Series, No. 3475

Egger, P., and Winner, H., (2005). Evidence on Corruption as an Incentive for Foreign Direct Investment, European Journal of Political Economy, 21(4), 932-952

Ezeoha, A. E., and Cattaneo, N., (2011). FDI Flows to Sub-Saharan Africa: The Impact of Finance, Institution and Natural Resource Endowment, In: CSAE Conference 2011: Economic Development in Africa

Fung, K. C, and Siu, A., (2005). Hard or Soft? Institutional Reforms and Infrastructure Spending as Determinants of Foreign Direct Investments in China, Japanese Economic Review, 56(4), 408-416

Habib, M., and Zurawicki, L., (2002). Corruption and Foreign Direct Investment, Journal of International Business Studies, 33(2), 291-307

Hymer, S. H., (1976). The International Operations of National Firms: A Study of Direct Foreign Investment, MIT Press, (C) 1976

Ivohasina, R., and Hamori, S., (2005). An Empirical Analysis of FDI Competitiveness in SubSaharan Africa and Developing Countries, Economics Bulletin, 6(20), 1-8

Kinda, T., (2010). Investment Climate and FDI in Developing Countries: Firm-Level Evidence, World Development, 38(4), 498-513

Kindleberger, C. P., (1969). American Business Abroad: Six Lectures on Direct Investment, New Haven and London: Yale University Press.

Kinoshita, Y., and Campos, N. F., (2002). The Location Determinants of Foreign Direct Investment in Transition Economies, Center for Economic Policy Research.

Kolstad, I., and Wiig, A., (2012). What Determines Chinese Outward FDI?, Journal of World Business, 47(1), 26-34

Lim, E., (2001). Determinant of, and the Relationship Between, Foreign Direct Investment and Growth: A Summary of Recent Literature, IMF Working Paper No. 01/175

Majeed, M. T., and Ahmad, E., (2008). Human Capital Development and FDI in Developing Countries, Journal of Economics Cooperation, 29(3), 79-104

Masuku, M. B., and Dlamini, T. S., (2009). Determinants of Foreign Direct Investment Inflows in Swaziland, Journal of Development and Agricultural Economics, 1(5), 177-184

Moosa, I. A., (2002). Foreign Direct Investment: Theory, Evidence and Practice, Palgrave Publishers.

Mottaleb, A. K., and Kalirajan, K., (2010). Determinants of Foreign Direct Investment in Developing Countries: A Comparative Analysis, The Journal of Applied Economic Research, 4(4), 369-404

Nagesh, K., (1994). Determinants of Export Orientation of Foreign Production by US Multinationals: An Inter-Country Analysis, Journal of International Business Studies, 25(1), 141-156

Onyeiwu, S., and Shresthe, H., (2004). Determinants of Foreign Direct Investment in Africa, Journal of Developing Societies, 20(1-2), 89-106

Pigato, M., (2000). Foreign Direct Investment in Africa: Old Tales and New Evidence, Africa Region Working Paper Series No. 8

Pradhan, J. P., (2010). Strategic Asset-Seeking Activities of Emerging Multinationals: Perspectives on Foreign Acquisitions By Indian Pharmaceuticals MNEs, Organisation and Markets in Emerging Economies, 1(2), 9-31

Tsen, W. H., (2005). The Determinants of Foreign Direct Investment in the Manufacturing Industry of Malaysia, Journal of Economic Cooperation, 26(2), 91-110

Udoh, E., and Egwaikhide F. O., (2008). Exchange Rate Volatility, Inflation Uncertainty and Foreign Direct Investment in Nigeria, Botswana Journal of Economics, 5(7), 14-31

UNCTAD, (2012). World Investment Report 2011, (C) United Nations 
US Energy Statistics, (2013). US Energy Information Administration

Wadhwa, K., and Reddy, S., (2011). Foreign Direct Investment into Developing Asian Countries: The Role of Market Seeking, Resource Seeking and Efficiency Seeking Factors, International Journal of Business Management, 6(11), 219-226

Waldkirch, A., (2011). Comparative Advantage FDI? A Host Country Perspective, Review of World Economics, 17, 485-505

WDI, (2012). World Development Indicators (WDI), World Bank, Washington DC WGI, (2012). World Governance Indicators (WGI), World Bank, Washington DC 